\title{
KARAKTERISTIK PERTANGGUNGJAWABAN KORPORASI PADA TINDAK PIDANA PERUSAKAN LINGKUNGAN HIDUP DI INDONESIA
}

\author{
Ni Kadek Eny Wulandari Putri, Fakultas Hukum Universitas Udayana, e-mail: \\ Enywulandari18@gmail.com \\ Kadek Agus Sudiarawan, Fakultas Hukum Universitas Udayana, e-mail: \\ agus_sudiarawan@unud.ac.id
}

doi: https://doi.org/10.24843/KS.2020.v08.i11.p05

\begin{abstract}
ABSTRAK
Tujuan yang ingin dicapai dalam penelitian hukum ini adalah untuk mengetahui korporasi ketika menjadi subyek hukum pidana dalam Undang- Undang Perlindungan dan Pengelolaan Lingkungan Hidup serta untuk mengetahui pertanggungjawaban pidana korporasi terhadap perusakan lingkungan hidup yang disebabkan oleh pembuangan limbah produksi ke sungai. Metode yang digunakan dalam penulisan jurnal ini adalah metode penelitian hukum normatif dengan menggunakan pendekatan perundang- undangan. Penulisan jurnal ini menggunakan dengan cara mengkaji dari bahan hukum primer yakni peruu serta bahan hukum sekunder yaitu doktrin atau teori yang didapatkan dari literatur hukum dan penelitian ilmiah. Hasil penelitian menunjukkan karakteristik korporasi sebagai subyek hukum pidana adalah di dirikan oleh perorangan, memiliki kekayaan sendiri terpisah dengan kekayaan yang mendirikan maupun pengurusnya, memiliki hak dan kewajiban disamping hak dan kewajiban pendiri dan pengurusnya. Bentuk dari pertanggungjawaban korporasi jika terbukti melanggar izin lingkungan dengan membuang limbah ke sungai akan dikenakan sanksi berupa sanksi administratif paksaan pemerintah, dibekukannya izin lingkungan atau dicabutnya izin lingkungan sesuai pasal 76 Undang- Undang Perlindungan dan Pengelolaan Lingkungan Hidup.
\end{abstract}

Kata kunci : subyek pidana, pertanggungjawaban, , perusakan, korporasi

\begin{abstract}
The objective to be achieved in this legal research is to identify corporations when they become criminal law subject in Environmental Preservation and Management Constitution as well as to know corporate criminal liability for environmental destruction caused by disposal of production waste into rivers. The method used in writing this journal is a normative legal research method using a statutory approach. The writing of this journal uses primary legal materials, namely peruu and secondary legal materials, namely doctrines or theories obtained from legal literature and scientific research. The results show that the characteristics of a corporation as a subject of criminal law are that it is established by individuals, has its own separate assets from the assets of the founder and management, has rights and obligations in addition to the rights and obligations of its founders and managers. The form of corporate responsibility if proven to have violated environmental permits by dumping waste into the river will be subject to sanctions in the form of administrative sanctions imposed by the government, freezing of environmental permits or revocation of environmental permits in accordance with Article 76 Environmental Preservation and Management Constitution.
\end{abstract}

Keywords: subject of crime, responsibility, vandalism, corporation 


\section{Pendahuluan}

\subsection{Latar Belakang}

Lingkungan hidup yang sehat merupakan bagian dari hak manusia berserta makhluk hidup disekitarnya untuk dapat menikmatinya tanpa pengecualian. Agar dapat lingkungan yang baik dan sehat tentu menjadi tugas semua orang untuk selalu menjaga dan melestarikan lingkungan hidup. Saat ini keberlangsungan lingkungan hidup yang bersih dan sehat semakin berkurang, masalah ini diakibatkan karena beberapa faktor. Faktor pertama ialah karena bumi yang kita tempati saat ini sudah semakin tua, dan faktor lainnya disebabkan oleh aktivitas yang dilakukan oleh manusia.

Manusia merupakan faktor kedua bagi kelestarian lingkungan hidup, sekaligus peran dan tanggungjawab manusia untuk selalu memberdayakan lingkungan untuk menjaga kelangsungan hidup ekosistem. Tetapi pada kenyataannya untuk bisa memenuhi kepuasan hidup, seringkali manusia menjadi pemicu terjadinya kerusakan lingkungan untuk memenuhi kepentingan pribadi tanpa memperdulikan keadaaan lingkungan. Sikap egois manusia menguasai alam hanya untuk mencapai kepuasan yang menjadi pendorong munculnya kegiatan eksploitasi sumber daya alam secara berlebihan. ${ }^{1}$ Bukan hanya untuk kepentingan pribadi, perusakan lingkungan juga dilakukan dalam kegiatan usaha. Bahkan dalam kegiatan usaha dapat menyebabkan perusakan lingkungan yang lebih banyak daripada kegiatan pribadi.

Biasanya kegiatan usaha yang kecil dapat dikerjakan secara perorangan (privat), tapi ketika usaha yang dijalankan merupakan usaha yang besar dan memerlukan adanya kerjasama dan keburuhan yang diperlukan meningkat dalam menyikapi era globalisasi, maka munculnya badan usaha di dunia perindustrian memiliki peran penting dalam pembangunan di era globalisasi. Korporasii adalah nama yang biasa digunakan dalam kelompok ahli hukum pidana untuk mengatakan nama itu didalam bidang hukum lain, seperti hukum perdata, sebagai badan hukum. Dengan adanya korporasi ini banyak mendatangkan keuntungan bagi masyarakat maupun negara, seperti pemasukan pajak dan devisa, membuka lapangan pekerjaan. Disamping mendapatkan keuntungan, adanya korporasi membawa dampak negatif yaitu pencemaran lingkungan (udara, air, tanah), eksploitasi sumber daya alam yang secara berlebihan, bersaing secara tidak sehat dan masih ada beberapa dari dampak negatif dengan adanya korporasi ini. ${ }^{2}$

Untuk penegakan hukum pada kasus- kasus mengenai perusakan lingkungan hidup terdapat sanksi yang mempunyai sifat kepidanaan dan sanksi administratif. Terlebih lagi dapat memungkinkan terdapat gugatan berupa mengganti kerugian dan atau melakukan pertanggungjawaban lainnya seperti mengembalikan guna

1 Karim,Abdul. "Mengembangkan kesadaran melestarikan lingkungan hidup berbasis humanisme pendidikan agama." Edukasia: Jurnal Penelitian Pendidikan Islam 12, no. 2 (2018): 312-313

2 Kusumo, BambangAli. "Pertanggungjawaban Korporasi dalam Hukum Pidana di Indonesia" Wacana Hukum 7, no. 2 (2012), hlm. 52-53 
lingkungan yang telah dirusak melewati gugatan keperdataan di pengadilan negeri. ${ }^{3}$ Penegakan hukum pidana bagi pelaku kejahatan dibidang lingkungan hidup guna memberikan efek jera terhadap pelaku itu sendiri. Hukum pidana juga menjadi ultimum remedium, yaikni cara terakhir untuk menentukan sikap semua orang khususnya penjahat dan memberi tekanan psikologis sehingga penjahat tersebut tidak lagi melakukan kejahatan. ${ }^{4}$ Tujuan dikenakan sanksi pidana adalah agar lingkungan hidup lebih terlindungi dari kejahatan maupun unsur-unsur lingkungan hidup itu sendiri.

Badan usaha sebagai subjek hukum terdapat dalam pasal 1 angka 32 UU. No. 32 tahun 2009 tentang Perlindungan dan Pengelolaan Lingkungan Hidup (yang selanjutnya akan disingkat menjadi Undang - Undang PPLH) menyebutkan bahwa "Setiap orang adalah orang perseorangan atau badan usaha, baik yang berbadan hukum maupun yang tidak berbadan hukum."

Dalam konteks kejahatan korporasi yang sering menjadi perhatian salah satunya adalah kejahatan terhadap lingkungan hidup. Korporasi kerapkali lalai dengan kondisi dari lingkungan disekitar usaha dan produksinya hingga seringkali menyebabkan perusakan lingkungan yang besar baik secara kuantitas maupun kualitas kerusakannya. ${ }^{5}$

Dari beberapa jurnal ilmiah yang sudah menggunakan tema mengenai analisis terhadap pertanggungjawaban korporasi sebagai subyek hukum lingkungan hidup, diantaranya ada jurnal ilmiah yang ditulis oleh Zul Akrial dan Heni Susanti dalam jurnal ilmiah UIR Law Review 1, no. 01 (2018) dengan judul “ANALISIS TERHADAP KORPORASI SEBAGAI SUBYEK HUKUM DIDALAM UNDANG- UNDANG No. 32 TAHUN 2009 TENTANG PERINDUNGAN DAN PENGELOLAAN LINGKUNGAN HIDUP". Perbedaan dengan jurnal ini ialah pembahasannya akan berbeda dengan jurnal ilmiah yang telah disebutkan diatas. Dalam jurnal ini akan lebih mengkhusus membahas mengenai karakteristik korporasi sebagai subyek hukum pidana dan mengenai bentuk pertanggungjawaban korporasi terahadap perusakan lingkungan. Oleh sebab itu, pada saat ini penulis tertarik untuk menulis jurnal ilmiah dengan judul "KARAKTERISTIK PERTANGGUNGJAWABAN KORPORASI PADA TINDAK PIDANA PERUSAKAN LINGKUNGAN HIDUP DI INDONESIA".

\subsection{Rumusan Masalah}

Dari penjelasan latar belakang tersebut, bisa kita rumuskan dua permasalahan seperti:

3 Mardiya, Nuzul Qur'aini. "Pengaturan pertanggungjawaban korporasi dalam tindak pidana lingkungan hidup/the regulation of corporate liability in environmental criminal act." Jurnal Hukum dan Peradilan 7, no. 3 (2018):488-489.

4 Barus, Kariawan. "Analisis Yuridis Pemidanaan Terhadap Korporasi Yang Melakukan Tindak Pidana Di Bidang Lingkungan Hidup Berdasarkan Undang-undang Nomor 32 Tahun 2009 Tentang Perlindungan Dan Pengelolaan Lingkungan Hidup (PPLH)." Master's thesis, 2011.5

5 Kurniawan, Ridho. "Pertanggungjawaban Pidana Korporasi Berdasarkan Asas Strict Liability (Studi Pembaharuan Hukum Pidana Lingkungan Hidup)." Jurnal Yuridis 1, no. 2 (2017): 155 
1. Bagaimana karakteristik korporasi sebagai subyek hukum pidana dalam Undang- Undang No. 32 Tahun 2009 Tentang Perlindungan dan Pengelolaan Lingkungan Hidup?

2. Bagaimana bentuk dari pertanggungjawaban pidana korporasi terhadap perusakan lingkungan hidup yang disebabkan oleh pembuangan limbah produksi ke sungai?

\subsection{Tujuan Penulisan}

Dalam penulisan jurnal ini memiliki dua tujuan yakni pertama, untuk mengetahui korporasi sebagai subyek hukum pidana dalam UUPPLH bentuk dari pertanggungjawaban pidana korporasi terhadap perusakan lingkungan hidup yang disebabkan oleh pembuangan limbah produksi ke sungai.

\section{Metode Penelitian}

Metode yang digunakan dalam penulisan jurnal ini adalah metode penelitian hukum normatif dengan menggunakan pendekatan perundang- undangan. Metode penelitian normatif merupakan penelitian hukum lewat sudut pandang internal melalui obyek penelitiannya yakni norma hokum. 6 Penulisan jurnal ilmiah mempergunakan sumber menggunakan cara mengkaji bahan hukum primer yakni peruu serta bahan hukum sekunder yaitu doktrin ataupun teori yang didapatkan dari kepustakaan hukum dan penelitian ilmiah. Dan selanjutnya dihubungkan pada pembahasan korporasi sebagai subyek hukum pidana dalam Undang- Undang PPLH dan bentuk dari pertanggungjawaban pidana korporasi terhadap perusakan lingkungan hidup yang disebabkan oleh pembuangan limbah produksi ke sungai.

\section{Hasil dan Pembahasan}

3.1 Karakteristik korporasi sebagai subyek hukum pidana dalam UndangUndang No. 32 Tahun 2009 Tentang Perlindungan dan Pengelolaan Lingkungan Hidup.

Korporasi merupakan salah satu badan yangg dibuat oleh hokum. Badan tercipta melalui "corpus", yakni badan fisiknya serta kedalamnya hokum memasukkan unsur "animus" telah memuat badan tersebut memiliki kepribadian. Sebab itu badan hokum adalah ciptaan dari hokum, karena itu hilangnyapun ditentukan oleh hukum. Didalam hukum pidana, korporasi terdiri dari badan hukum dan bukan badan hukum. Tidak hanya perhimpunan yang sudah disahkan menjadi badan hokum yang bisa dikategorikan sebagai korporasi, melainkan sesuai dengan hukum pidana firma, persekutuan komanditer atau Commanditaire Vennotschap (CV) dan persekutuan, yakni

6 I Made Pasek Diantha, 2016, Metodelogi Penelitian Hukum Normatif dala Justifikasi Teori Hukum, (Jakarta,Prenada Media Group), 12 
badan usaha. Sedangkan badan usaha bagi hukum perdata tidak termasuk badan hukum. ${ }^{7}$

Dalam Kitab Undang - Undang Hukum Pidana (KUHP) hanya terdapat orang perorangan "naturlijke person" yang menjadi subyek hukum pidana. Sementara korporasi tidak dapat dikategorikan sebagai subyek hukum pidana. Didalam perkembangan, dapat dilihat dari hukum pidana khusus diantaranya adalah UU No 7 Drt. Th. 1955, UU No 31 Th. 1999 yang telah dirubah dengan UU No 20 Th. 2001 tentang Perubahan atas UU No 31 Th. 1999 tentang Pemberantasan Tindak Pidana Korupsi, maupun dalam peraturan perundang- undangan sektoral yang memuat ketentuan pidana, seperti UU No 32 Th. 2009 tentang Perlindungan dan Pengelolaan Lingkungan Hidup, UU No 22 Th. 2001 tentang Minyak dan Gas Bumi, UU No 41 Th. 1999 tentang Kehutanan, UU No 4 Th. 2009 tentang Mineral dan Pertambangan Batubara dan yang lainnya. Dari ketentuan undang- undang tersebut, dapat diketahui bahwa korporasi sudah dapat dikatakan sebagai subyek hukum pidana. ${ }^{8}$

Hukum lingkungan termasuk dalam hukum pidana khusus karena aturanaturan yang terdapat dalam hukum lingkungan berbeda dari hukum pidana umum. Perbedaan ini mengenai ketentuan tersebut hanya digunakan pada subyek hukum tertentu ataupun mengatur suatu perbuatan yang tertentu. Di dalam hukum pidana khusus ini, Sudarto menyebutkan beberapa istilah undang- undang pidana khusus yang diklasifikasikan menjadi 3 kategori yakni UU yang tidak dikodifikasikan (Ongecodificeerd Strafrecht), Peraturan - peraturan hukum Administrasi yang mengandung sanksi pidana, dan UU yang mengandung hukum pidana khusus yang mengatur tentang tindak pidana bagi golongan tertentu / perbuatan tertentu. Dari klasifikasi tersebut hukum lingkungan terdapat pada klasifikasi Peraturan- peraturan hukum Administrasi yang mengandung sanksi pidana.

Pada Asas Societas Delinquere Non Potest ini meberikan jawaban kenapa didalam KUHP tidak dapat menemukan korporasi merupakan subyek hukum. Pengertian dari subyek hukum yaitu semua yang memiliki hak dan kewajiban. Hak yang dimaksud merupakan kekuasaan dan/ atau kekuasaan yang diberi oleh hukum kepada subyek hukumnya. Dan kewajibannya yaitu beban yang diberi oleh hukum kepada subyek hukumnya. ${ }^{9}$ Seperti yang telah dijelaskan sebelumnya seiring dengan berjalannya perkembangan hukum sekarang ini, korporasi dapat dianggap sebagai subyek hukum pidana.

Putri, Tri Tuti Aditama, and Ismail Ismail. "ANALISIS YURIDIS TERHADAP PERTANGGUNG JAWABAN PIDANA KORPORASI DALAM TINDAK PIDANA PENCEMARAN LINGKUNGAN." JURNAL PIONIR 5, no. 4 (2019),121.

8 Ratomi, Achmad. "Korporasi Sebagai Pelaku Tindak Pidana (Suatu Pembaharuan Hukum Pidana Dalam Menghadapi Arus Globalisasi Dan Industri)." Al-Adl: Jurnal Hukum 10, no. 1 (2018), 3-4

9 Disemadi, Hari Sutra, and Nyoman Serikat Putra Jaya. "Perkembangan Pengaturan Korporasi Sebagai Subjek Hukum Pidana Di Indonesia." Jurnal Hukum Media Bhakti 3, no. 2 (2019), 121 
Dalam Undang- Undang PPLH Pasal 1 angka 32 telah dikenalkan korporasi merupakan subyek hukum yang diatur dan mengatur lebih jauh tentang pertanggungjawaban korporasi. Pada pasal 116 Undang- Undang PPLH dijelaskan mengenai tindak pidana lingkungan hidup yang dikerjakan oleh, untuk, ataupun atas nama badan usaha, dalam penuntutan serta saksi pidana bisa dijatuhkan kepada korporasi dan / atau pengelolanya. ${ }^{10}$

Sama dengan konsep yang ada dalam Undang - Undang PPLH, dalam kententuan tindak pidana terdapat dalam UU terdapat 4 hal yang dapat diperhatikan, Satu, dalam Undang - Undang PPLH pelaku tindak pidana disamping perorangan dapat berupa badan hukum ataupun perserikatan, organisasi dan sejenisnya, sementara dalam KUHPidana yang dapat dijadikan pelaku hanya berupa manusia atau orang. Dua, Undang - Undang PPLH selain mempergunakan sanksi pidana pokok dan pidana tambahan layaknya pada KUHPidana mempergunakan tindakan tata tertib untuk memenjaga norma. Tiga, dalam rumusan pemidanaan terdapat norma yang kabur yang mempergunakan kata "dan/atau" membuat hukum bimbang untuk menjatuhkan sanksi kumulatif atau alternatif, terakhir yaitu Undang- Undang PPLH melihat hukum pidana sebagai ultimum remedium untuk tindak pidana formil tertentu, sedangkan tindak pidana lain mempergunakan asas premum remedium ( mendahului pelaksana penegakan hukum pidana). Undang - Undang PPLH masih belum memadai untuk pemidanaan untuk oknum dari tindak pidana lingkungan. Meskipun beberapa pasal yang dijelaskan bisa diperbaiki untuk dijadikan petunjuk didalam menyusun RKUHP yang diatur secara tersirat mengenai pelaku tindak pidana lingkungan untuk dijatuhkan sanksi yang berat baik perorangan maupun korporasi. ${ }^{11}$

Karakteristik badan hukum sebagai subyek hukum pidana adalah perorangan yang menjadi pendirinya, memiliki kekayaan tersendiri terpisah dengan kekayaan yang mendirikan maupun pengurusnya, memiliki hak dan kewajiban disamping hak dan kewajiban pendiri maupun pengurusnya. Hakekatnya korporasi memiliki perbedaan pada subyek hokum orang. Orang menjadi subyek hokum mempunyai jiwa dan sikap batin, korporasi tidak mempunyai sikap batin (mens rea). Jiwa dan sikap batin korporasi terdapat dalam pengurusnya yang bertindak untuk ataupun atas nama korporasi. Mens Rea adalah ketentuan yang diharuskan terdapat dalam pertanggung jawaban korporasi. . Selain itu, korporasi tidak dapat hadir secara pribadi di persidangan. Hal tersebut yang membuat berbeda antara subyek hukum alamiah (manusia) dengan subyek hukum korporasi. Berhubungan mengenai asas kesalahan yakni : Nulla poena sine culpa (tiada pidana tanpa kesalahan), dengan itu hanya subyek hukum pidana yang memiliki mens rea yang dapat dibebani pertanggung jawaban pidana. Subyek hokum yang tidak mempunyi sikap batin tidak dapat diberikan

10 Safitri, Fatimah Dwi. "Pembubaran Korporasi yang Melakukan Tindak Pidana Pencucian Uang dan Tindak Pidana di Bidang Lingkungan Hidup." Jurist-Diction 3, no. 1 (2020):96

11 Ridwansyah, Muhammad. "PENGATURAN TINDAK PIDANA DALAM UNDANGUNDANG NOMOR 32 TAHUN 2009 TENTANG PERLINDUNGAN DAN PENGELOLAAN LINGKUNGAN HIDUP (Tinjauan Fiqh Al-Bi'ah)." Jurnal Hukum dan Peradilan 6, no. 2 (2017):182. 
pertanggungjawaban pidana. Oleh sebab tersebut korporasi sebagai subyek hokum pidana tidak bisa dipertangung jawabkan secara pidana. ${ }^{12}$

\subsection{Bentuk dari pertanggungjawaban pidana korporasi terhadap kerusakan lingkungan hidup yang disebabkan oleh pembuangan limbah ke sungai}

Tindakan penemaran akan menimbulkan perusakan bagi lingkungan baik secara tidak langsung maupun secara langsung. Perusakan yang diakibatkan dapat membahayakan kelangsungan hidup semua orang dan dapat dijerat menggunakan pidana. Tujuan dari penerapan hukum pidana adalah untuk menjagajiwa dan kehormatan manusia serta harta benda. Pada saat KUHPidana dirancang, permasalahan lingkungan tidak mendapatkan sorotan dari banyak orang seperti sekarang ini. Saat itu persoalan mengenai lingkungan tidak muncul sebagai ancaman yang serius untuk keberlangsungan hidup manusia sebab industri saat itu tidak seberkembang seperti sekarang ini.

TP lingkungan sama dengan delik lingkungan merupakan perintah serta larangan uu kepada subyek hokum, jikalau dilanggar akan mendapat ancaman berupa dijatuhkan sanksi pidana, diantaranya pidana penjara dan pidana denda yang bertujuan melidungi lingkungan secara menyeluruh maupun unsur- unsur dalam lingkungan hidup. Delik lingkungan bukan saja mengenai ketentuan pidana yang terdapat dalam Undang - Undang PPLH, tapi terdapat pula yang sudah dirumuskan kedalam peruu lainnya selagi rumusan ketentuan tersebut menunjukkan untuk melindungi keseluruhan lingkungan hidup. ${ }^{13}$

Dalam bidang industri yang menjadi salah satu sumber dari kerusakan lingkungan terdapat beberapa izin, antara lain Izin Usaha Industri (IUI), Izin Hinder Ordonanntie (HO), Izin Pembuangan Air Limbah (IPLC), Izin Lokasi, Izin Dumping dan Izin Pengelolaan Limbah B3. Tetapi sejak berlakunya Undang - Undang PPLH sebagian dari izin tersebut diintegrasikan menjadi izin lingkungan dimana sudah tercantum dalam Pasal 123 Undang - Undang PPLH. ${ }^{14}$

Pelanggaran dan ketentuan pidana dalam UUPPLH terdapat dari pasal 98 sampai dengan 120. Penjelasan mengenai pertanggungjawaban korporasi ditetapkan pada pasal 116 hingga pasal 120 Undang - Undang PPLH.

1. Pasal 116 Undang - Undang PPLH:

Pada pasal ini menetapkan tentang siapa yang akan bertanggungjawab atas tindak pidana yang diperbuat oleh, untuk dan atas nama badan usaha/ korporasi. Untuk mengetahui siapa yang akan bertanggungjawab, harus diketahui bagaimana model dari pertanggungjawaban tersebut. contoh pertanggung jawaban korporasi ini dapat diamati dari jabatan dan sifat

12 Anjari, Warih. "Pertanggungjawaban Korporasi Sebagai Pelaku Tindak Pidana." E-Journal Widya Yustisia 1, no. 2 (2017). 118-119

13 Siregar, Januari, and Muaz Zul. "Penegakan Hukum Dalam Tindak Pidana Lingkungan Hidup Di Indonesia." Jurnal Mercatoria 8, no. 2 (2015): 119

14 Rahmadi, Takdir, Hukum Lingkungan Di Indonesia (Jakarta, PT. RajaGrafindo Persada, 2011) 117. 
pertanggungjawabannya seperti: pengelola sebagai pembuat jadi pengelola sebagai penanggungjawab, koorporasi menjadi pembuat tetapi pengelola yang diserahkan tanggungjawab, dan koorporasi yang membuat sekaligus sebagai penanggungjawabnya.

2. Pasal 117 Undang - Undang PPLH :

Di pasal 117 membahas mengenai ancaman pidana. Menetapkan ancaman pidana ditujukan yang meberikan perintah atau pimpinan tindak pidana diberatkan $1 / 3$ ancaman pidana, jadi yang di tuntut dan dijatuhi hukumannya adalah pengelola. Maksudnya yang di dakwa adalah pribadi pengurusnya. Dan ancaman yang telah dijatuhkan terhadap pengelola yakni ancaman penjara sekaligus denda.

3. Pasal 118 Undang - Undang PPLH:

Pasal 118 membahas mengenai tuntutan pidana yang dijatuhkan kepada pimpinan dari koorporasi badan hukum karena tindak pidana badan usaha merupakan tindak pidana fungsional hingga pidana maupun sanksi yang ditetapkan terhadap mereka yang mewakilkan kewenangan dari pelaku fisik. Artinya yang menjadi penanggungjawab atas tindakan fisik yang dimungkinkan akan terjadi tindakan pidana.

4. Pasal 119 Undang - Undang PPLH :

Dalam pasal 119 membahas mengenai selain pidana sanksi yang dapat dikenakan. Sanksi tersebut berupa pidana tambahan atau tindakan tata tertib, yaitu: dirampasnya keuntungan dari tindakan pidana yang dilakukan, ditutupnya sebagian maupun seluruh tempat kegiatan usaha, pembenahan terhadap lingkungan yang telah dilakukan tindak pidana, dan lainnya.

5. Pasal 120 Undang - Undang PPLH:

Secara keseluruhan pasal ini baik ayat (1) dan ayat (2) mengatur tentang tata cara eksekusi kepada badan usaha yang telah diberikan sanksi pidana tambahan ataupun tindakan tata tertib. ${ }^{15}$

Tanggung jawab korporasi tindak pidana lingkungan hidup terdapat juga didalam UU No 40 Th 2007 Tentang Perseroan Terbatas. Dimana dalam uu itu menyatakan bahwa Direktur tidak bisa membebaskan diri dari pertanggung jawaban pidana didalam perusahaan yang sedang di pimpinnya yang sudah merusak atau mencemari lingkungan. Begitu pula pada UUPPLH juga menentukan mengenai pertanggung jawaban bisa dijatuhkan pada badan hukum dan pimpinannya secara bersamaan, dalam soal kegiatan dan /atau korporasi yang dijalaninya menyebabkan pencemara dan / atau perusakan lingkungan. Selain itu UUPPLH ada juga aturan penanganan perkara di Mahkamah Agung yaitu Peraturan Mahkamah Agung

15 Dayani, Rizka Junisa, and A. M. Pujiyono. "Pertanggungjawaban Pidana Korporasi terhadap Pembuangan Limbah ke Media Lingkungan Hidup tanpa Izin (Studi Kasus Putusan Pengadilan Negeri Ungaran No. 62/pid. sus/2013/pn. ung)." Diponegoro Law Journal 6, no. 1 (2016): 5-6 
Republik Indonesia Nomor: 36/KMA/SK/II/2013 Tentang Pemberlakuan Pedoman Penanganan Perkara Lingkungan Hidup. ${ }^{16}$

Mengenai pertanggungjawaban korporasi beberapa ahli membaginya kedalam pendekatan- pendekatan yang telah diterapkan oleh negara- negara besar seperti Amerika Serika, Belanda, Australia, dan Perancis. Dan di Indonesia sendiri seprtinya belum menetapkan pendekatan yang mana akan diterapkan. Dapat kita lihat dari putusan yang ada seperti Putusan Mahkamah Agung pada Kasus RI v. Kim Young Woo (2010) dan Putusan MA dalam Kasus Republik Indonesiav. Ibrahim Lisaholit (2012) menunjukkan bahwa Mahkamah Agung belum dapat membedakan diantara subyek hukum korporasi dengan subyek hukum perorangan. Kedua subyek hukum tersebut dinilai sama karena perbuatan subyek hukum satu mengindikasikan subyek hukum lainnya. ${ }^{17}$

Ada salah satu berita mengenai pembuangan limbah yang dilakukan oleh korporasi di Provinsi Aceh. Sebagaimana berita ada adalah : 3 usaha sawit yang beroperasi di Rawa Tripa dilaporkan Panglima Laot Lhok Kuala Seumayam, Kecamatan Darul Makmur, Kabupaten Nagan Raya, ke Dinas Lingkungan Hidup Kabupaten Nagan Raya, Provinsi Aceh. Perusahaan yang dilaporkan melalui surat resmi tanggal 24 Juli 2020 itu adalah PT. Kallista Alam, PT. Socfindo, dan PT. Raja Marga. Dalam surat yang ditandatangani empat kepala desa itu, Kuala Seumayam, Blag Luah, Alue Bateung Brok, dan Desa Ujong Tanjong, disebutkan bahwa perusahaan tersebut membuang limbah hasil olahan sawitnya ke Sungai Seumayan. Limbah tidak hanya mencemari air tetapi juga membuat masyarakat gatalgatal. Dinas Lingkungan Hidup Nagan Raya akan menindak lanjuti laporan tersebut dan bersama Dinas Lingkungan Hidup dan Kehutanan Provinsi Aceh akan meninjau langsung lokasi. ${ }^{18}$

Berita tersebut baru terjadi dan belum ketiga perusahaan sawit dikenakan sanksi yang sesuai. Dan dari berita tersebut salah satu korporasi menyangkal mereka tidak ada membuang limbah sawit ke sungai yang telah disebutkan. Secara umum Korporasi dalam berita tersebut sudah melanggar dari bunyi pasal 65 Undang- Undang PPLH dan pasal 67 Undang- Undang PPLH. Dari kejadian tersebut dapat kita ketahui bahwa untuk menjatuhkan ancaman pidana kepada korporasi yang telah melakukan perusakan lingkungan hidup harus dengan hati- hati dan melalui banyak tahapan, karena sebelum menjatuhkan sanksi yang telah dijabarkan sebelumnya harus diselidiki apakah sudah ada izin pengolahan limbah B3, apakah hasil limbah yang

16 Palasi, Ryan. "PERTANGGUNGJAWABAN PIDANA KORPORASI DALAM PENCEMARAN DAN KERUSAKAN LINGKUNGAN HIDUP." PhD diss., Universitas Pembangunan Nasional Veteran Jakarta, 2014. 2-3

17 Wibisana, Andri G. "Kejahatan Lingkungan Oleh Korporasi: Mencari Bentuk Pertanggungjawaban Korporasi Dan Pemimpin/Pengurus Korporasi Untuk Kejahatan Lingkungan Di Indonesia?." Jurnal Hukum \& Pembangunan 46, no. 2 (2016): 152- 189

18 Sumber berita https://www.mongabay.co.id/2020/08/22/sungai-tercemar-limbahmasyarakat-nagan-raya-laporkan-tiga-perusahaan-sawit-ke-dinas-lingkungan-hidup $/$, diakses pada tanggal 3 September 2020; pukul 22.14 wita. 
dialirkan tersebut tidak melebihi baku mutu air sungai, dan masih banyak lagi yang harus ditinjau. Dalam menjatuhkan sanksi pidana kepada korporasi harus sesuai dengan siapa yang membuat dan siapa yang akan bertanggungjawab atas pembuangan limbah sawit ke sungai, berapa lama ancama pidana dijatuhkan kepada pengurus atau pemimpin korporasi, apakah korporasi tersebut mendapatkan pidana tambahan atau tindakan tata tertib, dan yang terakhir eksekusi ancaman pidana yang dijatuhkan kepada korporasi yang bersangkutan. Perusakan lingkungan yang paling sering kita lihat salah satunya adalah perusakan baku mutu air terutama pada air sungai yang disebabkan industri konveksi yang berada disekitar sungai tersebut. Pertanggungjawaban hukum oleh penanggungjawab usaha industri yang menyebabkan perusakan tersebut jika benar melanggar izin lingkungan akan dikenakan sanksi berupa sanksi administratif, paksaan pemerintah, dibekukannya izin lingkungan atau dicabutnya izin lingkungan sesuai dengan Pasal 76 Undang Undang PPLH. ${ }^{19}$

\section{Kesimpulan}

Karakteristik korporasi sebagai subyek hukum pidana adalah didirikan oleh perorangan, mempunyai kekayaan tersendiri dan terpisah dari kekayaan pendiri maupun pengurusnya. Korporasi tidak mempunyai jiwa dan sikap batin (mens rea). Jiwa dan sikap batin tersebut diwujudkan oleh pengurusnya yang bertindak untuk ataupun atas nama korporasi. Mens Rea merupakan syarat dari pertanggungjawaban korporasi. Untuk bentuk pertanggungjawaban korporasi jika ternyata benar melanggar izin lingkungan dengan misalnya membuang limbah ke sungai akan dikenakan sanksi berupa surat teguran, paksaan pemerintah, dibekukannya izin lingkungan atau dicabut izin lingkungan sesuai dengan pasal 76 Undang- Undang PPLH.

\section{DAFTAR PUSTAKA}

\section{Buku :}

I Made Pasek Diantha, 2016, Metodelogi Penelitian Hukum Normatif dala Justifikasi Teori Hukum, (Jakarta,Prenada Media Group)

Rahmadi, Takdir, Hukum Lingkungan Di Indonesia (Jakarta, PT. RajaGrafindo Persada, 2011)

\section{Hasil Penelitian:}

Palasi, Ryan. "PERTANGGUNGJAWABAN PIDANA KORPORASI DALAM PENCEMARAN DAN KERUSAKAN LINGKUNGAN HIDUP." PhD diss., Universitas

Barus, Kariawan. "Analisis Yuridis Pemidanaan Terhadap Korporasi Yang Melakukan Tindak Pidana Di Bidang Lingkungan Hidup Berdasarkan Undang-undang Nomor 32 Tahun 2009 Tentang Perlindungan Dan Pengelolaan Lingkungan Hidup (PPLH)." Master's thesis, 2011.5

19 Artana, I. Made Yudi, I. Nyoman Putu Budiartha, and I. Nyoman Sutama. "Pertanggungjawaban Hukum Pelaku Usaha Konfeksi terhadap Pencemaran Sungai di Kota Denpasar." Jurnal Analogi Hukum 1, no. 2 (2019): 236 


\section{Jurnal Ilmiah:}

Karim,Abdul. "Mengembangkan kesadaran melestarikan lingkungan hidup berbasis humanisme pendidikan agama." Edukasia:Jurnal Penelitian Pendidikan Islam 12, no 2 (2018): 312-313

Kusumo, BambangAli. "Pertanggungjawaban Korporasi dalam Hukum Pidana di Indonesia" Wacana Hukum 7, no 2 (2012), hlm. 52-53

Mardiya, Nuzul Qur'aini. "Pengaturan pertanggungjawaban korporasi dalam tindak pidana lingkungan hidup/the regulation of corporate liability in environmental criminal act." Jurnal Hukum dan Peradilan 7, no 3 ( 2018 ):488-489.

Kurniawan, Ridho. "Pertanggungjawaban Pidana Korporasi Berdasarkan Asas Strict Liability (Studi Pembaharuan Hukum Pidana Lingkungan Hidup)." Jurnal Yuridis 1, no. 2 (2017): 155

Putri, Tri Tuti Aditama, and Ismail Ismail. "ANALISIS YURIDIS TERHADAP PERTANGGUNG JAWABAN PIDANA KORPORASI DALAM TINDAK PIDANA PENCEMARAN LINGKUNGAN." JURNAL PIONIR 5, no. 4 (2019),121.

Ratomi,Achmad. "Korporasi Sebagai Pelaku Tindak Pidana (Suatu Pembaharuan Hukum Pidana Dalam Menghadapi Arus Globalisasi Dan Industri)." Al - Adl: Jurnal Hukum 10, no 1 (2018), 3-4

Disemadi,Hari Sutra, and Nyoman SerikatPutra Jaya. "Perkembangan Pengaturan Korporasi Sebagai Subjek Hukum Pidana Di Indonesia." Jurnal Hukum Media Bhakti 3, no 2 (2019), 121

Safitri, Fatimah Dwi. "Pembubaran Korporasi yang Melakukan Tindak Pidana Pencucian Uang dan Tindak Pidana di Bidang Lingkungan Hidup." JuristDiction 3, no. 1 (2020):96

Ridwansyah, Muhammad. "PENGATURAN TINDAK PIDANA DALAM UNDANGUNDANG NOMOR 32 TAHUN 2009 TENTANG PERLINDUNGAN DAN PENGELOLAAN LINGKUNGAN HIDUP (Tinjauan Fiqh Al-Bi'ah)." Jurnal Hukum dan Peradilan 6, no. 2 (2017):182.

Anjari,Warih. "Pertanggungjawaban Korporasi Sebagai Pelaku Tindak Pidana." EJournal Widya Yustisia 1, no. 2 (2017). 118-119

Siregar, Januari, dan MuazZul. "Penegakan Hukum Dalam Tindak Pidana Lingkungan Hidup Di Indonesia." Jurnal Mercatoria 8, no 2 (2015): 119

Wibisana,Andri G. "Kejahatan Lingkungan Oleh Korporasi: Mencari Bentuk Pertanggungjawaban Korporasi Dan Pemimpin/Pengurus Korporasi Untuk Kejahatan Lingkungan Di Indonesia?." Jurnal Hukum \& Pembangunan 46, no 2 (2016): 152- 189

Dayani, Rizka Junisa, and A. M. Pujiyono. "Pertanggung jawaban Pidana Korporasi terhadap Pembuangan Limbah ke Media Lingkungan Hidup tanpa Izin (Studi Kasus Putusan Pengadilan Negeri Ungaran No. 62/pid. sus/2013/pn. ung)." Diponegoro Law Journal 6, no. 1 (2016): 5-6

Artana, I. Made Yudi, I. Nyoman Putu Budiartha, and I. Nyoman Sutama. "Pertanggungjawaban Hukum Pelaku Usaha Konfeksi terhadap Pencemaran Sungai di Kota Denpasar." Jurnal Analogi Hukum 1, no. 2 (2019): 236

\section{Peraturan perundang - undangan}

Undang- Undang Dasar Negara Republik Indonesia Tahun 1945

Undang- undang No. 32 tahun 2009 tentang Perlindungan dan Pengelolaan Lingkungan Hidup, Lembaran Negara Republik Indonesia, Tambahan Lembaran Negara Republik Indonesia. 
Mahkamah Agung yaitu Peraturan Mahkamah Agung Republik Indonesia Nomor: 36/KMA/SK/II/2013 Tentang Pemberlakuan Pedoman Penanganan Perkara Lingkungan Hidup.

\section{Internet:}

Sumber berita https://www.mongabay.co.id/2020/08/22/sungai-tercemar-limbahmasyarakat-nagan-raya-laporkan-tiga-perusahaan-sawit-ke-dinas-lingkunganhidup/, diakses pada tanggal 3 September 2020; pukul 22.14 wita. 